ARTICLE

DOI: $10.1057 /$ s41599-018-0148-y

\title{
Policy change and the narratives of Russia's think tanks
}

Edwin Bacon ${ }^{1}$

ABSTRACT Russia's ruling regime, dominated by Vladimir Putin since he first became president in 2000, is often seen as presenting a consistent and coherent narrative and allowing little space for plurality of opinions. While it is the case that at the level of metanarrative, a consistent official story of a Russia resurgent both domestically and internationally has been told, analysis of the work of think tanks within the purview of Russia's political leadership reveals that conflicting narratives remain at play within the regime's political tent. Analysis of a decade of think tank activity shows that the Medvedev presidency (2008-2012) saw the rise and then decline of the liberal INSOR think tank, while the most prominent think tank in Putin's third term as president (2012-2018) was the anti-liberal Izborskii Club, which followed a similar pattern of waxing and waning prominence. From the point of view of Russia's leadership, the existence of these think tanks has a functionalist explanation, allowing what is essentially a non-ideological regime to engage with and adopt different positions according to its proximate requirements. Such a functionalist approach runs the risk of undermining the coherence and persuasiveness of the regime's narrative(s). From the point of view of the political science classification of the extant Russian regime, Russia's post-Soviet 'transition' remains to be resolved in terms of its chosen course even a quarter of a century on from the collapse of Communism.

\footnotetext{
${ }^{1}$ University of Lincoln, Lincoln, UK. Correspondence and requests for materials should be addressed to E.B. (email: ebacon@lincoln.ac.uk)
} 


\section{Introduction}

arrative analysis as a scholarly tool for investigating the beliefs and policy preferences of Russia's ruling regime has come to the fore in recent years (Bacon, 2012; Chatterje-Doody, 2014; Bacon, 2015; Miskimmon and O'Loughlin, 2017). It relies on analysing the expressed worldview of Russia's rulers and those associated with them, and identifying these as narrative parts such as-to amalgamate the typological frameworks of Bacon (2012) and Miskimmon et al. (2013)agents (characters), acts (plots and subplots), temporalities (beginnings and endings), space (setting), central purpose (motif), and agency (symbols and tools). Taking this approach has tended to find a consistency of narrative in the story told by Russia's leaders during the Putin era (2000-2018) in terms of broad positioning. Analysts are by now familiar with Russia's autobiographical narrative of a Russian state insistent on its great power status, willing to work with the West but spurned in its efforts to build a mutually acceptable post-Cold War security system; keen to abide by international law but reluctantly and rarely, for example in Crimea, transgressing its letter for reasons of defending itself and its people. In domestic politics, the accompanying story is of a country rising from the poverty and political chaos of the 1990s, brought on by adherence to inappropriate Western political and economic models, and bringing to its people in their stead stability, economic growth, and national pride in the face of Western attempts to undermine the same.

This article does not seek to analyse the accuracy of Russia's narrative from an empirical perspective. Rather it focuses on the discourse itself to ask whether it is quite as coherent as our opening summary suggests. Specifically, it asks how the idea of a consistent Putin-era narrative (2000-2018) deals with the fact that Vladimir Putin's third term (2012-2018) is widely acknowledged to have seen an authoritarian turn after the, outwardly at least, more liberal stance of the Medvedev presidency (2008-2012). How can we speak of narrative consistency in the face of Russia's significant shifts in stance and policy? The question is not new. Analysts have previously addressed the idea of multiple views within Russia's regime system through the concept of 'managed pluralism' (Balzer, 2003); noted how Russia's 'strong state' allows but contains differing political perspectives through the 'managed democracy' of its electoral system (Tsygankov, 2014: pp. 130-140); and considered the balance between 'coercive and mobilising measures' as the Russian state has sought to 'manage' disparate, often anti-regime, nationalist forces for its political purposes (Laine, 2015: p. 35).

The particular contribution of this paper is to analyse how Russia's ruling regime engages with favoured think tanks to develop and deploy narrative shifts within its stable system. Through considering in particular the discourse of a think tank that rose to prominence during Putin's third presidential term and represents a broad 'imaginary' on which aspects of his narrative have drawn-the conservative and nationalist Izborskii Club-I argue that the multiplicity of epistemological frames and concomitant policy proposals at play inside Russia's ruling tent throws the notion of a single neat narrative into disarray once disaggregated beyond the most broad-brush of metanarrative. The rise and relative decline of the Izborskii Club's prominence during Putin's third term has similarities, as our later analysis demonstrates, with the fate of President Medvedev's preferred think tank, the liberal Institute for Contemporary Development (INSOR).

Beyond identifying, through think tank focused analysis, the variety of narratives bumping up against one another within Russia's 'ideological ecosystem' (Laruelle, 2017), I argue that this surprising lack of ideational homogeneity reflects well the nature of Russia's ruling regime from both an immediate and a teleological perspective. As the final section concludes, the continued presence of ideologically divergent think tanks within the ambit of the ruling regime has potential benefits and hazards, as well as preserving an openness regarding the future path to be taken by the extant regime or its successor. The following section sketches the benefits, hazards, and future options stemming from existence of a variety of narratives; these are returned to in more detail towards the end of this paper.

In proximate policy terms, the Russian élite that came to power at the turn of this century has been consistent in its preference for pragmatism rather than grand schemes. Both journalistic insider accounts and quantitative coding-based political science analysis have Putin as an opportunist rather than an ideologically driven strategist (Zygar', 2016; Dyson and Parent, 2018). The maintenance of an array of potential policy positions within the frame of an overarching unifying narrative has the benefit of facilitating programmatic flexibility. In the terms deployed within narrative analysis, the existence of subplots alongside the central plot serves to keep options open, and characters in play, so that they can be brought to the fore or discarded without undermining the main plot and central characters (Bacon, 2012: pp. 780-781).

There exists, however, a hazard that accompanies this benefit. The flipside of such programmatic flexibility is that when competing subplots become simultaneously or too closely identified with the ruling regime, any convincing and coherent central plot is weakened. In President Putin's third term (2012-2018), and particularly since Russia's annexation of Crimea in 2014, international criticism of Russia's policy discourse repeatedly sought to highlight a lack of consistency, and indeed to accuse Russia of purposefully seeking to undermine narrative coherence and encourage a 'post-truth' environment. Russian troll farms and bots have sought to undermine 'mainstream' narratives in order to influence political debate and voting behaviour (Abrams, 2016; Prier, 2017). Such relatively hidden and deniable behaviour has been accompanied by more open deployment of contradictory and incongruous statements by Russian officials and by Russian 'mainstream media'. The long-noted consistency of Russia's official narrative (Miskimmon and O'Loughlin, 2017: p. 118) becomes undermined by such inconsistencies. For example, a setpiece international interview with President Putin in 2018 spent more time than he appeared comfortable with questioning his credibility by challenging his apparently contradictory statements surrounding events in Crimea in 2014

[Armin Wolf, Interviewer:] Many people do not believe Russian arguments because a few years ago in Crimea you said that the famous 'green men,' the fighters in green uniforms without identifying insignia, were all local selfdefence forces. But a little later it was revealed that they were indeed Russian soldiers. After that, you admitted many times that those were Russian army personnel even though you denied that earlier. Why should we believe you now? (President of Russia, 2018)

The Skripal poisoning case in the United Kingdom in 2018 similarly led UK officials to emphasise Russian inconsistency over 'more than 30 contradictory and changing fantasies to explain the Salisbury attack' (Foreign and Commonwealth Office, 2018), and the UK Foreign Secretary to accuse Russia of producing a 'torrent of absurdity' around the attempted murder (Johnson, 2018a).

Aside from the benefit and hazards of narrative variety when it comes to immediate policy, in future-oriented teleological terms the ebbs and flows of markedly differing streams of thought and regime-friendly think tanks in Russian political life over the past 
decade or so speak more to what Sergei Prozorov terms the 'suspension of the teleological time', in which the failure of any particular pathway to the future to gain hegemonic status is evidenced by the 'coexistence of radically incompatible potentialities' within the regime's purview (Prozorov, 2008: pp. 219-220). In other words, that different narratives remain in play reveals a Russia the nature of whose long-term future settlement remains unresolved.

\section{Russia's think tanks in comparative perspective}

The scholarly justification for considering the narratives of selected think tanks when considering the policy frame within which the Putin regime operates in Russia rests on two factors. First, political think tanks, by their nature across the world in the current era, tend towards an open but partisan stance in which they analyse issues and push policy proposals within a broad but identifiable political frame. We are used to think tanks in the United Kingdom being designated by the BBC, for example, as right of centre, left of centre, pro-European, free market, and so on. Similarly, in the United States a think tank might be known for being conservative or neo-con, liberal or progressive. The political stance is apparent, and the think tank's research and policy proposals reflect that stance. As set out in more detail below, the situation in non-democratic states such as Russia and China is less open, but nonetheless analogous. Some political space exists for the exploration and promotion of policy ideas that are not simply dictated by the state, and this section on Russia's think tanks in comparative perspective places such organisations within that context. Second, the most recent two presidential terms in Russia-that of Dmitrii Medvedev (2008-2012) and Vladimir Putin (2012-2018) - have been marked by differentiated political discourses and an evident shift in the think tank landscape as regards closeness to the incumbent president. We return to this later when, having covered comparative and definitional questions, the article considers the waxing and waning of the influence of different think tanks in line with Russia's change of both president and political emphasis.

I consider first the position of think tanks in Russia within the context of wider scholarly research into political think tanks. The definition of think tanks has, even in the limited literature on that phenomenon, inevitably been open to debate. As Andrew Rich sets out, there has been 'considerable disagreement' over which institutions belong in this category, and in any case 'drawing irrefutable distinctions between think tanks and other types of organisations is neither entirely possible nor desirable' (Rich, 2004: p. 11). Rich asserts that think tanks must be distinguished from university-based research institutes, government research organisations, and research outfits attached to particular interest and lobby groups. Independence from government, political parties, and interest groups stands as an essential characteristic in the literature on think tanks in the West. Think tanks are nonprofit groups that seek to influence policy and the wider public through analysis and intellectual argument, rather than through direct lobbying (Stone, 1996: p. 16). The aspect of public engagement, alongside-or hand in hand with-the influencing of policy represents a further defining element of think tanks. Stone emphasises that they are 'public-spirited' in that they seek to educate and act in the interests of the wider community, while Rich posits a more utilitarian motive for public engagement, namely that think tanks are 'aggressive institutions' made up of 'aggressive advocates for ideas and ideologies' out to maximise public credibility in order to enhance their policy influence (Rich, 2004: pp. 6, 11).

The question of independence in relation to think tanks has two aspects, which have drawn attention in the literature on the subject, namely, institutional independence and intellectual independence. There are numerous accounts, which pay little heed to definitional precision in relation to think tanks in both Western and non-Western settings. Of particular relevance to this article's focus on the Izborskii Club, a nationalist policy-focused organisation in contemporary Russia, Marlène Laruelle's empirically rich paper on 'the new nationalist think tanks in Russia' (Laruelle, 2009) applied the term to a range of groupsincluding those attached to the Soviet government, university centres, public opinion pollsters, discussion clubs, and marketing consultancies-but without engaging with issues of definition. Both of the key definitional aspects, namely institutional independence and intellectual independence, require further development when it comes to distinguishing think tanks in nonWestern settings.

Zhu Xufeng argues that it is inappropriate to simply adopt Western definitional criteria when assessing think tanks in China, where, if such criteria were to be strictly applied, 'there are no such organisations' because the one-party political system means that virtually all Chinese think tanks are government-funded or have some connection with the government ( $\mathrm{Zhu}, 2009$ : pp. 336-337). In fact, the question of financial independence lacks defining rigour in both the Western and the Asian settings, since many Western think tanks have funding which stems, either directly or indirectly, from the public purse. The second aspect of independence-intellectual independence-relates on one level then to the question of financial independence. Although funding may come from governmental sources, think tanks in receipt of such resources 'maintain their 'academic' or research freedom and are not beholden to any specific interest' (Stone, 1996: p. 16). In the Chinese case, Zhu prefers the term 'autonomy' to independence. He affirms that research agencies established within government structures cannot be called think tanks, but argues that 'semi-official' public institutions outwith the structures of government are sufficiently autonomous to fit the definition. Such organisations-for example, the Chinese Academy of Social Sciences, and the Shanghai Institute for International Studies-are not completely independent of government but they have the autonomy to accept research commissions from external, including international, clients and to criticise government policies (Zhu, 2009: p. 337).

The intellectual independence of think tanks clearly demands that they are free to discover and report what their research finds, without their voices being 'bought' by government or interest groups. Independence of this order may even be a legal requirement, for example, in terms of think tanks' formal legal or fiscal status. The semi-official think tanks in our Chinese example are legally constituted as 'public institutions' as opposed to 'government agencies'. In the United States the tax-exempt status of nonprofit think tanks depends on them not seeking to directly influence legislation or elections (Rich, 2004: p. 18). Such formal designations do not, however, capture a more nuanced aspect of intellectual independence, which is particularly pertinent to our discussion of Russia's Izborskii Club, namely, ideological independence and stance. The Izborskii Club is vehemently statist, anti-Western and ultra-conservative (within Russian terms, which allows self-avowed Marxists of the Soviet-nostalgist type to qualify as conservative). However detailed its analysis and output on any given topic may be, there is never any doubting the main thrust of its conclusions. What price intellectual independence in such a context? Can the term 'think tank' be applied to a group whose work is so restricted within ideological bounds? Does the ultra-conservative nature of this particular ideology delegitimise the Izborskii Club's conceptualisation as a think tank?

These questions have much in common with debates surrounding the use of the term 'civil society' within the Russian 
context, and some might argue that to call the Izborskii Club a think tank is to generate a similar example of the inappropriate stretching of Western concepts. The categorisation of the proKremlin youth organisation Nashi illustrates well the analogy (Atwal and Bacon, 2012). Linz and Stepan define civil society as made up of groups, which operate in the political arena and have a relationship with the state, but do not seek to occupy it (Linz and Stepan, 1996). Nashi would fit these criteria, but not match the more stringent Gramscian criterion of engaging in an antithetical 'war of position' between state and civil society (Chebankova, 2013: p. 103). Others likewise take a normative position in contending that the term civil society must apply only to those groups, which pursue what might broadly be defined as a democratic goals (Putnam et al., 1993; Evans et al., 2006: p. 4). Drawing these elements together, although a pro-Kremlin (indeed Kremlin-instigated) group such as Nashi occupies a position within the space of, and performs some of the same functions as, civil society, its political and ideological position makes for problematic categorisation. Is a group with a pro-Putin position and a penchant for occasional engagement in the contentious politics of the street, not better categorised as part of uncivil rather than civil society? Kopecký and Mudde argue rather that category decisions ought not to be based on subjective assessment of political positions-who is in and who is out in terms of international, for which read 'Western', political opinion-but rather on empirical assessments of associational life in a country as a whole (Kopecký and Mudde, 2003: pp. 15, 160-161).

The debate around the use of the term 'civil society' within the Russian context resonates with this article's contention that the Izborskii Club can be usefully and legimitately analysed within the frame of wider literature on think tanks. Although its ideological and political position does not sit within the standard Western democratic pale, in its intent to support the Eurasianist and statist turn in Russia since 2012 and to argue for further moves in that direction, the Izborskii Club nonetheless fills the space and performs the functions of a think tank. The definition is applied functionally, not normatively. Furthermore, developments within think tank studies more broadly provide backing for the Izborskii Club's inclusion within this category. First, as noted above, studies of think tanks in China have retained the key defining elements of intellectual and financial independence but nuanced them in a country-specific manner. In terms of these defining criteria, the Izborskii Club appears in any case to be institutionally and intellectually free of Russia's ruling regime. Even while taking a semi-supportive position in relation to the regime during Putin's third term, it criticises the regime too and its claim to independence is bolstered by its participants, many of whom have been vociferously critical and independent for years, even decades, in their assessment of post-Soviet Russia. Second, the past few decades have seen a clear ideological turn in the nature of think tank research in the West. Andrew Rich set out the two central questions, which shape his book Think Tanks, Public Policy, and the Role of Expertise:

Have think tanks generally evolved from producing painstaking research and objective writing to pursuing ideological agendas with far-reaching impact in the war of ideas? If so, what accounts for these transformations, and what are their consequences for the role and influence of their products-expertise and ideas-in American policy making? (Rich, 2004: p. 2)

Rich argues that between the 1960s and the twenty-first century in the United States, the role of think tanks changed to become less objective and more ideological, and with it the public perception of experts has shifted. No longer are experts 'neutral, credible, and above the fray of the rough and tumble of policy making', instead they 'now behave like advocates ... not just visible but highly contentious as well'. They actively market their work, which often consists of 'pre-formed views rather than even attempts at neutral rational analysis' (Rich, 2004: pp. 2, 4-5). The idea that think tanks must engage, so far as possible, in objective research with no predetermined ideological standpoint went by the board a number of years ago in the West, as demonstrated in the United States by organisations such as the Heritage Foundation, Freedom House, and the Jamestown Foundation on the conservative wing, or the Progessive Policy Institute and the Institute for Policy Studies more towards the liberal end of the spectrum. Diane Stone, in her seminal study of think tanks, referred to what were then emergent organisations as ideological tanks' (Stone, 1996: p. 21).

When Russia's government began, during President Putin's second term in office (2004-2008), to express concern over the influence of Western non-governmental organisation (NGO) activity-including think tank activity_in Russia, the fact that many think tanks have ideological agendas was already wellestablished. In 2012 Russia introduced a law, which obliged all NGOs in Russia that receive funding from abroad and engage, even partially, in political activity to register as 'foreign agents'. While roundly criticised by Western governments, and NGOs themselves, for introducing vindictive and symbolic legislation, President Putin justified the law on the grounds that the public should be informed of the possible motives of these groups (Russia Today, 2014). The law's punitive sanctions consisted primarily of the perjorative labelling of these groups, thereby serving to designate two classes of NGO/think tank activity - 'ours' and 'theirs' - and fostering a growing popular discourse which contrasted, to borrow Caroline Humphrey's phrase, 'a Euro-Atlantic set of values' with Russian/Eurasian values (2002: p. 15). Against this background, the Izborskii Club represents the ideological flipside, namely, a think tank, which explicitly claims to promote, through the use of analytical reports, meetings, and publications, Russian and Eurasian positions in overt opposition to the Western values and 'solutions', which its members see as at best inappropriate for, and at worst-and more commonly-a deliberate 'threat to destroy Russia as a state' (Dugin, 2013: p. 75).

The final element to consider in our discussion of the Izborskii Club's definition as a think tank is the nomenclature used within Russia, and in particular the form of organisation known as an intellectual, or a political, club. The designation of think tanks as clubs has little equivalence in contemporary Western political life. Stone's chapter on foreign policy think tanks carries the title 'The Foreign Policy Club' (Stone, 1996), though this is not an analytical category, more an apparent reference to the notion that activist and ideological think tanks differ from the 'rather more idealistic, club-like and less hyper-active' institutes of the immediate post-war years (Higgott and Stone, 1994: p. 34). In Russia, the emergence of élite social clubs in Moscow and St. Petersburg in the post-Soviet era drew analytical comparisons with the élite clubs, both historical and contemporary, in London and various American cities, where networks of political and business élites develop (Leshukova, 2009). The Izborskii Club does not, however, fit into this category. Its self-designation as a club relates rather to the development of political 'clubs' within the political milieu of Putinism. Two particular manifestations stand out as relevant. First, the regime's 'party of power', United Russia, established within itself three 'political clubs' in 2008, representing the social-conservative, the liberal-conservative, and the state-patriotic elements within the party. The terminology 'club' sought to emphasise that these were not divisive factions prefiguring a damaging split in United Russia, whose very name serves to emphasise its deep distrust and fear of division. United Russia's clubs represent themselves as instruments for wide policy 
discussion, and not by any means as the early signs of competing political parties emerging from within the existing party of power (Shchipanov, 2008). Second, the Valdai Club, which was established in 2004 by the Putin regime to 'promote dialogue between Russian and international intellectual elites, and to make an independent, unbiased scientific analysis of political, economic and social events in Russia and the rest of the world' (The Valdai Discussion Club, 2018). The flagship event of the Valdai Club since its founding has been its annual meeting to which leading Western experts are invited and given the opportunity to question and discuss issues with Russia's president and prime minister. It is against this background that the Izborskii Club arrived at its title. Like the clubs of United Russia, the Izborskii Club does not represent an electoral challenge to the status quo. Although its political positions are more extreme than those common within United Russia, it nonetheless operates within the broad tent of Russia's current political settlement in that it is not calling for the current regime or institutional structures to be overthrown. Like the Valdai Club, the Izborskii Club takes its name from the place of its founding meeting. In so doing, it appears to have been stating at its foundation that the Valdai Club-of which Aleksandr Prokhanov, the Izborskii Club' founder, is a member-is its comparator, but that the Izborskii Club represents the 'antiValdai' tendency, a 'counter-liberal alternative to be developed by experts from the conservative patriotic camp' (Khamraev et al., 2012).

\section{Think tanks and Russia's presidents}

During the presidency of Dmitrii Medvedev (2008-2012) and the third term as president of Vladimir Putin (2012-2018), two think tanks with notably different political stances came to the fore. The main focus of this article is the nationalist-statist and anti-liberal Izborskii Club that was established in September 2012. In the preceding 4 years, however, the think tank that appeared to sit closest to the Russian president and garnered regular headlines for its reports and recommendations was the notably liberal Institute of Contemporary Development (INSOR-Institut sovremennogo razvitiya). INSOR was formally launched in spring 2008, at the same time as Dmitrii Medvedev was elected President of Russia. It emerged out of a think tank called the Centre for Development of the Information Society, and President Medvedev took a non-executive role as chair of INSOR's board of trustees. Throughout the Medvedev presidency, INSOR produced a range of reports that focused on the theme of modernisation. Although linked to the president, INSOR merited the term 'think tank' as its independence of thought within the broad framework of Medvedev's favoured subject of modernisation became clear. US scholar Jeffrey Mankoff noted at the time that INSOR issued 'public statements that go well beyond what Medvedev himself has called for' (2011: p. 77). In particular, INSOR's most high profile report, 21st Century Russia: the shape of a desirable future, called for comprehensive democratisation in Russian domestic politics, and for Russia to work towards eventual full membership of NATO and a close relationship with the Western powers (INSOR, 2010). Leaving aside analysis of actual policy decisions made by the regime, the frame of policy prescriptions put forward by President Medvedev's favoured think tank differs starkly from that to be found in élite discourse during President Putin's third term (2012-2018), marked as these latter years were by moves in an authoritarian direction and a ramping up of anti-westernism.

Since the end of the Medvedev presidency in 2012, INSOR has scarcely been heard from. It continues to exist, though greatly diminished in status. Its website has formal reports on its activities only for the years 2008 to 2011; and a link to the Institute's leadership, that used to in turn link to a page showing Medvedev as chair of the trustees, now returns the inquisitive reader to INSOR's home page. ${ }^{1}$ Figure 1 shows the decline in public prominence of the liberal INSOR think tank through the number of mentions it received in the Russian press during the Medvedev presidency and beyond, counting mentions in all of the newspapers and magazines available in the Eastview Russian Central Newspapers database, consisting of over 80 publications and including all of Russia's major news publications.

Turning from the liberal INSOR think tank to the anti-liberal Izborskii Club a similar pattern of rise and fall in terms of public prominence can be discerned, as Fig. 2 illustrates by means of a comparison between mentions of INSOR and of the Izborskii Club. Two caveats need to be noted in regard to this comparison. The first relates to temporalities. As the presidential term of Dmitrii Medvedev was 4 years and the third presidential term of Vladimir Putin was 6 years, Fig. 2 counts mentions for each quarter of the two presidential terms, allowing comparison over different lengths of time. As the membership of the Izborskii Club overlaps with that of the newspaper Zavtra, and Zavtra has assiduously promoted the Izborskii Club's activities, separate data

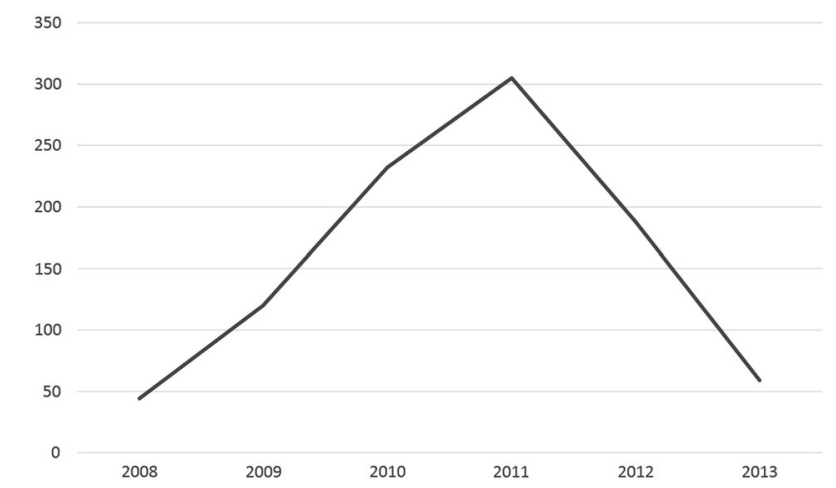

Fig. 1 Mentions of INSOR in Russian newspapers, 2008-2013. A line graph showing the number of mentions of INSOR in the Eastview database of Russian central newspapers, year by year, 2008-2013. Source: Calculated from search of Eastview's Russian Central Newspapers database

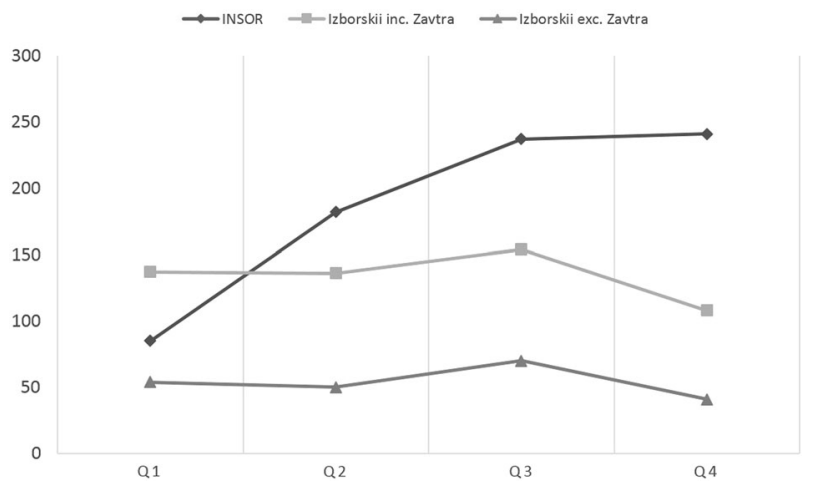

Fig. 2 Mentions of INSOR and the Izborskii Club in Russian newspapers, by each quarter of the respective presidential terms. A line graph showing the number of mentions of INSOR and the Izborskii Club in the Eastview database of Russian central newspapers comparing each quarter of two successive presidential terms, 2008-2012 and 2012-2018. One line for INSOR in all central newspapers, one line for the Izborskii Club in all central newspapers, and one line for the Izborskii Club in all central newspapers excluding Zavtra. Source: Calculated from search of Eastview's Russian Central Newspapers database. INSOR in the Medvedev term, 7 May 2008-6 May 2012. Izborskii Club in Putin's third term, 7 May 2012-6 May 2018 
for mentions of the Izborskii Club including and excluding mentions in Zavtra are used in Fig. 2. Furthermore, the sum of mentions of the Izborskii Club in the Russian press ends when Putin's third term concludes in 2018, whereas Fig. 1 draws on mentions of the INSOR think tank for more than a year beyond the end of President Medvedev's term in office.

Second, as the detailed analysis of the Izborskii Club below sets out, President Putin cannot be so closely identified with that think tank as can President Medevedev with INSOR. The argument of this paper does not though rely on claims of a close linkage, but rather argues that the discourse and narrative frame of the two think tanks under consideration here both feed into and reflect the narrative of the ruling regime. INSOR and the Izborskii Club were the most well-known think tanks on the Russian political scene in, respectively, the presidential terms of 2008-2012 and 2012-2018. President Medvedev encouraged INSOR, even though some of its conclusions were sharply critical of the political system of which he was-nominally at least-at the head, and some of its recommendations went way beyond what he might contemplate implementing. Despite the fact that, as Kenneth Wilson argues, 'Medvedev's reforms were not entirely cosmetic, but the results ... were very modest' (2015: p. 154), the narrative promoted by INSOR among others did change the terms of debate and at the very least create the setting in which the titular question of Wilson's article-was there a 'thaw' under Medvedev?-makes sense. Similarly, though in the opposite political direction, the Izborskii Club criticises President Putin at times and would like him to strike a stronger nationalist and statist path than he is inclined to. Marlène Laruelle argues convincingly, however, that following on from the anti-regime protests in Moscow during the final months of the Medvedev presidency, when Vladimir Putin returned as president 'the presidential administration welcomed new, better structured counter-ideologies... expressed in a grey area that is neither totally official nor totally dissident [but] ... draws on significant support' (Laruelle, 2016: p. 643).

As Fig. 2 shows, the number of mentions of the Izborskii Club in the Russian press was below that of the INSOR think tank. We can suggest potential reasons for this-such as the Izborskii Club not being so closely identified with the Head of State, having a political position less in tune with much of the press, issuing less focused reports in a less media friendly manner than INSOR-but beyond the aggregate numbers, the trend of a diminution in popular prominence from the third quarter of the presidential term onwards is comparable. In both cases we see a shift in the narrative in a distinct direction from newly established think tanks serving as a signal for the presidential term just beginning, with the impact of that new narrative stream declining as the presidential term moves towards its end.

\section{The Izborskii Club: Russia's anti-liberal 'super Think Tank'}

I turn now to focus on the Izborskii Club, with the central task of the following section being to identify the narrative themes and streams of this anti-liberal think tank's output. The Izborskii Club is an expert group made up of the some of the best known names in Russian state-patriotic politics. The permanent membership of this political club consists of 48 leading figures from across the socially conservative-statist spectrum who share a broad ideological approach, which they themselves term 'social conservatism' but is more commonly known within the academic literature as national patriotism. A critical western observer has designated the Izborskii Club as an intellectual circle situated within 'the extremely right-wing Russian political spectrum’ (Umland, 2008: p. 3). Chaired by veteran nationalist author, campaigner, and editor of the daily Zavtra ('Tomorrow'), Aleksandr Prokhanov, its membership includes such well-known figures as Eurasianist ideologue and sometime Moscow State University professor Aleksandr Dugin, Orthodox priest and best-selling author Arkhimandrite Tikhon, and economist and politician Sergei Glaz'ev. (For a full list and further details of all 48 permanent members of the Izborskii Club, see Table 1). Established in September 2012, in the historically significant Russian town of Izborsk not far from the Estonian border, the Izborskii Club achieved immediate prominence, as its ideologically driven analyses chimed with the increasingly conservative, statist, and Eurasianist tone of Vladimir Putin's third term as Russian President (2012-2018). The Izborskii Club's first analytical reports included warnings that 'a series of regional armed conflicts close to Russia's borders' was likely to soon arise (Delyagin et al., 2012: p. 72). When such conflicts came, with the annexation of Crimea and fighting in southern and eastern Ukraine in 2014, both the stock and the rhetoric of the Izborskii Club heightened.

In forming the Izborskii Club, its founders sought to bring together different streams within the national-patriotic movement, 'from socialists and Soviet patriots to monarchists and Orthodox conservatives' (Izborskii Club, 2013). Such an alliance of ideological streams by no means represents a new element in Russian political life. Over a quarter of a century ago, as the Soviet Union collapsed, conservative forces of the left and right began to look for ways to work together against what they conceptualised as the import of western liberalism, represented at the time by the policies of the last Soviet leader, Mikhail Gorbachev, and the first president of post-Soviet Russia, Boris Yeltsin. Groups such as the Co-Ordinating Council of the National-Patriotic Forces of Russia, the All-Russia Patriotic Movement 'Fatherland', the Russian People's Assembly, and the Russian National Council appeared and faded away, but the most significant of these groups was that established largely on the initiative of Aleksandr Prokhanov, the National Salvation Front (Fomenkov, 2008: p. 123). The foundational position of the National Salvation Front can be found in the Political Declaration of the Left and Right Opposition, published in the newspaper Den', edited by Prokhanov, in October 1992. This declaration defined the left-right alliance as the 'union of Red and White', referring to the two sides in Russia's postrevolutionary civil war between the Communist Bolsheviks and the monarchist Whites (Slater, 1998: p. 2). As the Soviet Union disappeared into history, a new Russia emerged declaring itself to be a market democracy re-joining-to use Vladimir Putin's phrasing in his Millennium Manifesto of 1999-the civilisational mainstream. The voices of the national-patriotic opposition seemed then to be little more than vain rants against the march of history. By 2012 the themes of the founding statement of Prokhanov's Izborskii Club remained the same, only now its authors represented their position as in line with that of Russia's leader:

The unity of two historical eras, the strategic reconciliation of 'reds' and 'whites' in the face of the liberal threat-this is the huge, world-scale task of genuine statesmen ... the impending Russian victory demands the unity of 'reds' and 'whites'. It demands the creation of a state in which, as V. V. Putin said, it will be possible to live as a 'red' commissar and a 'white' officer' (Izborskii Club, 2012a, b: p. 6).

In calling for the unity of 'reds' and 'whites', the Izborskii Club is in step with the Putin regime's long-standing commitment to national unity, and an end to the divisions in Russia that the collapse of the Soviet Union brought to the fore. President Putin himself has consistently mined this theme, symbolically promoting early in his first term the introduction of state symbols (flags, coats of arms, a national anthem) that drew on various historical periods. The 'red' stream of Soviet era nostalgia emphasises the role of the state, social justice, and scientific 


\section{Table 1 Membership of the Izborskii Club}

\section{Name \\ Born Short biography}

Aleksandr Prokhanov (Chairman)

1938 Prolific author, publicist, and editor in chief of the right-wing paper Zavtra. Prokhanov served as a foreign correspondent during the Brezhnev years, including in Afghanistan, Nicaragua, Cambodia, and Angola. During this time he wrote the first of his many novels, which tend to have military-geopolitical themes. As the Soviet Union collapsed, Prokhanov established the newspaper Den'. He supported the antiGorbachev coup of August 1991, and opposed President Yeltsin's attack on parliament in 1993. The government banned Den', and so Prokhanov established Zavtra. In the 2000s his novel Mr Hexagen dealt with the apartment bombings in Moscow in 1999, and The Fifth Empire developed a resurgent Russian imperial vision. In 2014, he published a novel called Crimea.

Vitalii Aver'yanov (Deputy Chairman) 1973 Russian Orthodox publicist, author, and philosopher. Aver'yanov graduated from the journalism faculty of Moscow State University in 1996 before going on to study philosophy. He wrote his candidate's dissertation on the problem of tradition in Russian twentieth century philosophy, and then worked at the Russian Academy of Science Institute of Philosophy. In 2009 he established the Institute of Dynamic Conservatism, that morphed into the Izborsky Club in 2012. The Izborsky Club's URL is www.dynacon.ru.

Aleksandr Nagorny (Deputy

Chairman)

1947 Political commentator on the 'patriotic' wing. Deputy editor of the newspaper Zavtra, and vice president of the Association of Political Experts and Consultants. Has worked at the Kurginyan Centre (also known as the Experimental Creative Centre).

Aleksandr Ageyev

1962 Economist. General Director of the Institute for Economic Strategy in the Russian Academy of Sciences Social Science Division. President of the International Academy for Future Studies. Member of the Russian Academy of Sciences Co-ordinating Council for Forecasting.

Zhores Alferov

1930 Awarded Nobel Prize for Physics, 2000. Professor in the Faculty of Electrical Engineering of Leningrad Electrical Engineering Institute in the 1970s and 1980s. Awarded the State Prize of the Soviet Union in 1984, and of the Russian Federation in 2001. Vice President of the Russian Academy of Sciences since 1991. Member of the Duma since 1995, elected via the Communist Party of the Russian Federation list.

Augustine (Anisimov) Bishop of Gorodets and Vetluga

1945 Born in Moscow during the Second World War, Anatolii Ivanovich Anisimov became involved with the Russian Orthodox Church in the early 1970s, during the Soviet era. He was ordained Deacon in 1990 and served for several years as a Missionary of the church, travelling widely and ministering in schools, prisons, the armed forces, and so on. He was made a Bishop in 2012 and became a Permanent Member of the Izborskii Club in November 2015.

Dmitrii Ayatskov

1950 Having worked as an agronomist during the late Soviet era, Ayatskov rose to prominence through local and regional government. He was Deputy Mayor of Saratov, 1992-1996, before becoming Governor of the Saratov region, 1996-2005. Became a Permanent Member of the Izborskii Club in November 2014, heading up its Saratov branch.

Sergei Batchikov

1953 Economist and businessman, with expertise in Latin America. Stood for parliament on the Communist Party of the Russian Federation list in 2005. Close ally of Sergei Glaz'ev, whose presidential campaign staff he led in 2004.

Vladimir Bol'shakov

1951 An academic during the Soviet era, specialising in International Relations. In the 1990s Bol'shakov engaged with politics, becoming a member of the Executive Committee of the Congress of Russian Communities, headed up by Dmitrii Rogozin. Since 2000, head of the department Fundamentals of Citizenship in the Russian Academy of Painting, Sculpture and Architecture, becoming pro-rector for scientific work in 2013.

Vladimir Bortko

1946 Worked in film, television and theatre since the Soviet era. A member of the Soviet Communist Party from 1983 until its dissolution in 1991, he became an active member of the Russian Communist Party, was elected to the State Duma in 2011 and re-elected in 2016.

Sergei Chernyakhovskii

Giulietto Chiesa

1956 Political philosopher and publicist. Member of the Public Chamber of the Ministry of Culture.

1940 Italian journalist and political activist. Member of the European Parliament 2004-2009. Member of the Italian Communist Party in the 1970s. Went to Russia as Moscow correspondent of Italian Communist newspaper L'Unità in 1980 and then Moscow correspondent of La Stampa. Has written many books on the Soviet Union and Russia, his later work focusing on Russophobia and various 'alternative' (that is, against the accepted line in the West) interpretations of events such as $9 / 11$ and the terrorist attacks of 2015 in Paris.

Mikhail Delyagin

1968 Chief editor of the leading Russian politics journal Svobodnaya mysl'. Prolific author, economist and politician. Advisor to various government figures including Boris Nemtsov (1997-98) and Mikhail Kasyanov (2002-2003).

Aleksandr Dugin

1962 Leading Eurasianist philosopher, polemicist, and writer. Between 2008 and 2014 he headed up the department of sociology of international relations at Moscow State University. Having been an antiCommunist in his youth, Dugin developed a geopolitical take on world affairs, developing Eurasianist and anti-Western ideas and becoming a significant voice in Russia both on the radical nationalist right and in official circles close to Putin.

Georgii Filimonov

1980 At university Filimonov gained a specialism in US affairs. He served in the Presidential Administration as a foreign policy adviser, before moving into the world of business. He then became an Assistant Professor, and later Professor, at the Russian University for the Friendship of Peoples.

Andrei Fursov

1951 Historian, academic, and publicist. Member of the advisory council of the journal Geopolitika, alongside Aleksandr Dugin.

Sergei Glaz'ev

1961 One of the initiators of the Izborsky Club, Glaz'ev is an advisor to President Putin on Eurasian integration. Economist, Minister for Foreign Economic Relations in Yeltsin's government (1992-1993), member of the State Duma (1994-1995, 2000-2007), one of the founders of the national-patriotic bloc Rodina. Stood in Russia's 2004 presidential election, gaining $4.1 \%$ of the vote. 
Table 1 (continued)

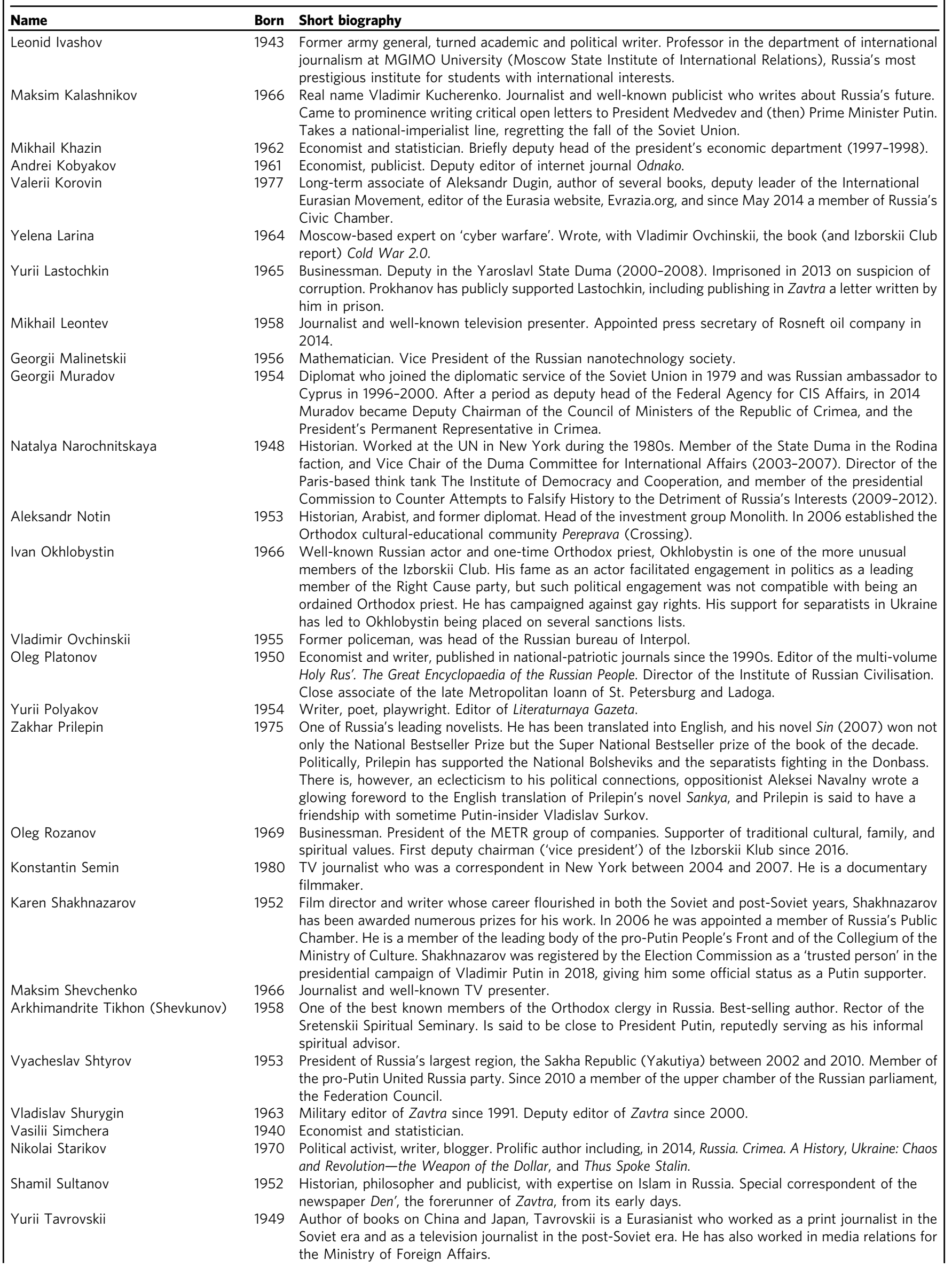


Table 1 (continued)

\begin{tabular}{lrl}
\hline Name & Born $\quad$\begin{tabular}{l} 
Short biography \\
\hline Sergei Tsekov
\end{tabular} $1953 \begin{array}{l}\text { Member of the upper house of the Russian parliament, the Federation Council, for Crimea. Appeared on } \\
\text { the EU sanctions list for his part in the annexation of Crimea. }\end{array}$ \\
Sergei Ushkalov & $1969 \begin{array}{l}\text { Participated in the Bryansk branch of the Izborskii Club since 2013, and became a Permanent Member of } \\
\text { the Izborskii Club in 2016. His biography on his own website is notably brief, remarking only that 'from } \\
\text { the middle of the 1990s he has been involved in entrepreneurial and social activities'. }\end{array}$ \\
$\begin{array}{l}\text { Artist (painter, cartoonist) whose work has been exhibited widely in Russia and internationally. Works } \\
\text { for Prokhanov's newspaper Zavtra and teaches art at the Russian State University for the Humanities. }\end{array}$
\end{tabular}

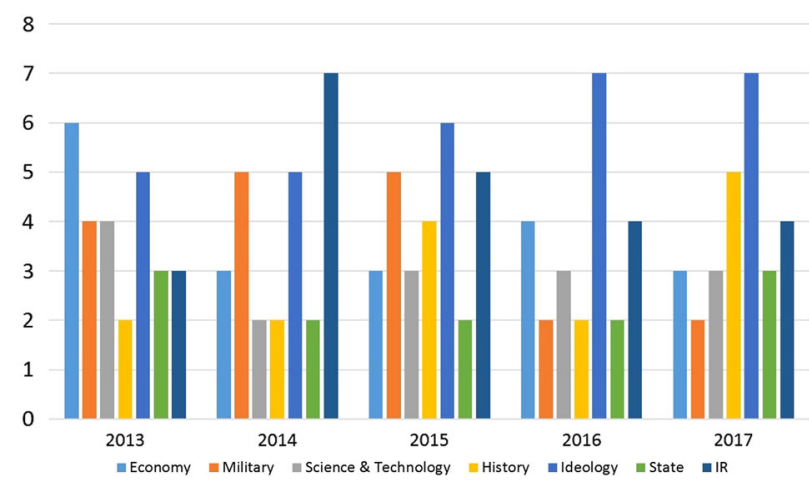

Fig. 3 The relative prominence of themes in the Izborskii Club magazine, 2013-2017. A column graph showing the relative prominence of each of seven themes in the Izborskii Club journal for each year, 2013 to 2017 inclusive. Source: Data coded from reading of all issues of the journal Izborskii Klub: Russkie strategii, 2013-2017. Vertical axis is the number of issues of the Izborskii Klub journal in which each theme has substantial articles devoted to it

progress, and the anti-Soviet 'white' stream draws on more esoteric concepts of Orthodoxy, traditional Russia, and nature. In Laruelle's words, the Izborskii Club seeks 'not to try to solve these differences, but to integrate them into a consensual metanarrative that allows for plurality of opinion within it' (2016: p. 635). Both 'red' and 'white' streams have Russia as, respectively, a superpower or an Imperial power on the world stage, shaping the fates of nations, particularly those in its contiguous sphere of influence.

Figure 3 draws on the Izborskii Club's monthly journal to show the relative prominence over time of these red-white themes. ${ }^{2}$ The Izborskii Club magazine, in some indication of the resources available to the think tank, is a well-produced publication of over a hundred pages lavishly illustrated with photographs and art work that even without words provide a sense of the themes at play (Bacon, 2017: p. 182). While most or all of the themes identified in Fig. 3 are present to some degree in each edition of the magazine, issues tend to have a dominant theme. To oversimplify, discussion of the economy, the military, and science and technology has a 'red' Soviet nostalgist tint; history and ideology tend more towards the the 'white'; and discussions of the state and IR (international relations) seek to synthesise policy propositions, although they carry the positional imprint of the particular author(s) writing each piece.

The trends apparent in Fig. 3 reflect developments in Russian politics at the same time as they try to influence them. Early on in President Putin's third term, the economy was to the fore, with the global financial crisis sparking the search for anti-liberal prescriptions in reaction to the overtly liberal modernisation proposals of the Medvedev presidency, as promoted by the INSOR think tank. The annexation of Crimea and conflict in Ukraine in 2014 brought military matters and Russia's international relations to the forefront of debate, and shaped political discussion in Russia for the following years. As the tumultous events of 2014 settled towards a new, albeit shaky, anti-western equilibrium, so an increasing emphasis on 'ideology' (for the most part, nationalist-civilisationalist Russian exceptionalism) became apparent in the Izborskii Club's work.

The significance of shifting narrative frames in Putin's Russia This article's analysis so far argues that although it is possible to identify a broad metanarrative of Russia as a resurgent great power told by the Putin regime since the turn of this century, a finer-grained story is necessary to make sense of the shifts in policy and positioning of the Russian state in the years between 2000 and 2018. Taking just the last decade of that period, it is evident from the shifting fortunes of the INSOR and Izorskii Club think tanks that the Russian leadership's narrative frame altered as the Medvedev presidency gave way to Putin's third term in 2012. Many of the Izborskii Club's members had been in opposition to Putin in the previous decade or so, albeit to varying degrees in terms of both the differing views of individual members, and the changing position of Vladimir Putin in a more nationalist and conservative direction as his time in power continued. By the time of President Putin's third term in office (2012-2018), the consistent ideological positions of the nationalpatriotic forces, as represented by the Izborskii Club, no longer represented a peripheral voice of protest as the policy and rhetoric of official Russia moved closer to their stance and embraced with enthusiasm ideas such as Eurasian unity, ethnic nationalism, and anti-westernism.

The notion that the Russian regime allows, even encourages, a broad range of often conflicting and poorly matched political positions to ebb and flow within the borders of (semi-)official political discourse does not sit well with the image that appears commonplace in much Western media that portrays contemporary Russia as an authoritarian state out to crush dissent, as if it were still the old Soviet state. The managed plurality apparent through analysis of those think tanks close to Russia's ruling regime is, however, entirely in line with the nature of the present Russian state. As noted earlier, the existence of several subplots within the Russian state's central narrative offers several benefits to Russia's rulers in terms of policy flexibility, keeping opposing political paths open within the frame of the extant regime. At the same time, such an approach has potential hazards, if the distance between regime and disparate narratives becomes too close and the central narrative too blurred. Finally, and stepping back from the immediate pros and cons of policy enactment and regime survival, the continued ebbing and flowing of different policy streams speaks of an as yet unresolved post-Soviet identity for Russia.

First, there are evident benefits for Russia's ruling regime in keeping differing policy and identity narratives, as represented by think tanks close to but separate from the authorities, within the overarching tent of the regime. From the point of view of classifying Russia's regime type in terms of democracy and authoritarianism, Russia retains a democratic constitution and 
institutional structure, but this framework of formal rights, regular multi-party elections, and a commitment to limits on how long one person can remain president is critically flawed from the democratic perspective by the fact that politics is so managed that the regime always retains power. Where the ruling regime has never been voted out of power, where there is no sign that this will ever be allowed to happen, there the designation of that state as a democracy is invalid, whatever the formal institutional arrangements. From this perspective, Russia is well described, to use Paul Brooker's typology of non-democratic regimes, as a nondemocratic state that seeks to disguise itself as a democracy in order to legitimise the power of its ruler(s) (Brooker, 2013: p. 225-254). A successful democratic disguise is one that looks as much like a democracy as possible without there being any risk that the regime lose power in elections. The incidental and comparatively derisory consolation of such an approach is that in a system like that, elements of democracy exist to the extent that they do not threaten the rulers' position. From this perspective, the existence of a plurality of worldviews expressed in think tanks and elsewhere enhances the democratic disguise, especially when the withdrawal of the regime's imprimatur appears to be sufficient-as in the case of INSOR and potentially in the future case of the Izborskii Club-for that think tank's influence to diminish. By encouraging such bounded plurality the regime ensures that there is no monolithic state ideology to support the designation 'authoritarian', while at the same time the state's influence is sufficient to fine-tune the multivocal mix as it desires.

Second, and largely in terms of international relations, there are clear hazards for Russia's regime the longer it seeks to hold onto multiple narratives within a central narrative that speaks of itself as a democratic great power committed to international law. The efficacy of political narratives is a factor of both their consistency and their empirical basis. As President Putin's third term progressed, it became increasingly commonplace for Western governments to accuse Russia of, in the words of British Prime Minister Theresa May, 'seeking to weaponise information ... in an attempt to sow discord in the West and undermine our institutions' (May, 2017). The British Foreign Secretary put it more strongly a few months after his Prime Minister when, in the wake of the poisoning of the former Russian double-agent Sergei Skripal in Salisbury, he talked of 'the wearying barrage of Russian lies, the torrent of obfuscation and intercontinental ballistic whoppers' (Johnson, 2018b). From the perspective of Russia 'weaponising information', the accusation is that it has sought to challenge the Western narrative not simply by having a counternarrative, but rather by promoting a sufficiency of inconsistent, even contradictory, narratives so that everyone might be able build their own version of truth, and in so doing undermine the notion of truth itself (Matthews, 2018). This is what Foreign Secretary Boris Johnson had in mind when he spoke of Russia's 'torrent of absurdity' (Johnson, 2018a).

To many observers who have read enough of the voluminous output of the Izborskii Club to get a sense of its content, the application of the adjective 'absurd' to significant elements of it does not seem out of place. The Izborskii Club's 'findings' include conspiracy-based metanarratives that talk of a coming catastrophe in which the world will need to continue technological progress whilst preserving humanism, with Russia 'the only part of humanity capable of performing this task' (Delyagin, 2013: p. 10). Or the notion of a secret Anglo-American society controlling world politics in the twentieth century, causing two world wars, and still existing today (Fursov, 2013). In amidst the huge amount of evidence-free, semi-formed ideas of the Izborskii Club there exist too some well argued conceptualisations and proposals, but much of the published material is closer to conspiratorial imaginings than reasoned analysis. It can seem as if, in Izborskii thinking, nothing ever happens because it happens, or because of evident causal factors, but rather because it is somehow willed by 'them', by the enemy.

It is important to emphasise again that the Izborskii Club does not represent the thinking of the Putin regime, any more than one of its leading members, Aleksandr Dugin, merits the title of 'Putin's Brain' bestowed on him by the journal Foreign Affairs (Barbashin and Thoburn, 2014). Nor indeed would the vast majority of Russians be aware of, let alone agree with, the detailed outpourings of the Izborskii Club. At the same time though, there exists a sizeable minority of Russians who would take an antiWestern stance. Two-thirds of Russians would like to see better relations with the West, and just under a third would prefer a diminution in contacts. More specifically, 48 per cent of Russians think that Russia should be open to better relations with the United States, whereas 52 per cent would prefer that Russia work to limit US influence and power (Levada Centre, 2018: p. 196, 201). Whatever the role that the multiple narratives of the Izborskii Club's broad red-white strands in terms of undermining Western narratives, there is no doubt that their common antiWestern, anti-liberal stance draws on and reflects a substantial body of domestic opinion.

Third, and finally, the range of different narratives represented by the think tanks in play around the Russian regime in the years 2008 to 2018 speak still of the unresolved nature of Russian's post-Communist transition. Although a strong case can be made for the idea of a socially conservative country with a great power complex returning to authoritarian type a quarter of a century after the Soviet collapse, having found itself unsuited to Westernstyle democracy and participation in the international system created by the West, such a case cannot be conclusive. Our analysis of the rise and fall of think tanks with markedly different narrative and policy frames shows, in Fig. 2, continued mobility, with the focus on the Izborskii Club and its nostalgist conceptualisations of Russia's future, beginning to decline. Opinion polls in 2017 reveal similar trends among Russia's people, with the dramatic dip in support for Russia becoming a western-style democracy that occurred at the time of the annexation of Crimea in 2014 seeing a dramatic reversal and the most popular option for Russia's ideal future-preferred by about a third of respondents-being for it to be 'like a developed Western country' with a market economy, democratic institutions and human rights (Levada Centre, 2018: p. 26, 34).

Such public opinion data show too, however, that Russians remain starkly divided about their-to borrow from the title of INSOR's most well-known report-desirable future. More may want Russia to have a Western-style market-democratic future than any other option, but plenty also hanker for a Soviet-style system or a Russo-specific path of development. Nor can we even state with certainty that the regime itself has settled on a consistent position. While it is difficult to imagine President Putin's fourth term seeing a return to the sort of liberal narratives of previous years, his annual 'state of the nation' address in 2018 majored on prosaic domestic priorities rather than on the esoteric philosophical and civilisational concerns of his 2013 and 2014 speeches. As this article has demonstrated through considering the narratives of think tanks, a range of discursive frames remains in play in Russia's élite-level politics as well as among its people. From the point of view of the political science classification of the extant Russian regime, Russia's post-Soviet 'transition' remains to be resolved in terms of its chosen course even a quarter of a century on from the collapse of Communism. 
Received: 20 April 2018 Accepted: 2 July 2018

Published online: 07 August 2018

\section{Notes}

1 Compare the link under the heading 'leadership' (rukovodstvo) http://www.insorrussia.ru/ru/\%252F that goes straight to the home page, with the still existing but unlinked page naming Medvedev as chairman of the trustees http://www.insor-russia. ru/ru/leadership/board_of_trustees (accessed 17 April 2018).

2 The data on which Fig. 3 draws are available from the author.

\section{References}

Abrams S (2016) Beyond propaganda: Soviet active measures in Putin's Russia. Connections: Q J 15(1):5-31

Atwal M, Bacon E (2012) The youth movement Nashi: contentious politics, civil society, and party politics. East Eur Polit 28(3):256-266

Bacon E (2012) Public political narratives: Developing a neglected source through the exploratory case of Russia in the Putin-Medvedev Era. Polit Stud 60 (4):768-786

Bacon E (2015) Putin's Crimea Speech, 18th March 2014: Russia's changing public political narrative. J Sov Post-Sov Polit Soc 1(1):13-36

Bacon E (2017) Inside Russian politics. Biteback Publishing, London

Barbashin A, Thoburn H (2014) Putin's brain: Alexander Dugin and the philosophy behind Putin's invasion of Crimea. Foreign Affairs. Available at: https://www.foreignaffairs.com/articles/russia-fsu/2014-03-31/putins-brain? cid=soc-facebook-in-snapshots-putins_brain-040114 (Accessed 18 April 2018)

Balzer H (2003) Managed pluralism: Vladimir Putin's emerging regime. Post-Sov Aff 19(3):189-227

Brooker P (2013) Non-democratic regimes. Palgrave Macmillan, Basingstoke Chatterje-Doody PN (2014) Harnessing history: Narratives, identity and perceptions of Russia's post-soviet role. Politics 34(2):126-137

Chebankova EA (2013) Civil society in Putin's Russia. Routledge, London

Delyagin M (2013) Demokratii i rynku konets. Izbor klub: Rus Strateg 1(9):7-10

Delyagin M et al. (2012) Strategiya 'Bol'shogo ryvka'. Izbor klub: Rus Strateg 1 (1):46-73

Dugin A (2013) Aleksandr Dugin: Russkii otvet na vyzov zapada. Izbor klub: Rus Strateg 1(1):74-79

Dyson SB, Parent MJ (2018) The operational code approach to profiling political leaders: understanding Vladimir Putin. Intell Natl Secur 33(1):84-100

Evans $\mathrm{AB}$ et al. (2006) Russian civil society: a critical assessment. M.E. Sharpe, Armonk, N.Y., London

Fomenkov AA (2008) Front natsional'nogo spaseniya i ego rol' v politicheskikh protsessakh v Rossii v 1992 godu. Nauchnye Vedom 42(6):123-129

Foreign and Commonwealth Office (2018) OPCW Executive Council meeting: 18 April update on the use of a nerve agent in Salisbury. Available at https:// www.gov.uk/government/speeches/opcw-executive-council-meeting-18april-update-on-the-use-of-a-nerve-agent-in-salisbury (Accessed 25 June 2018)

Fursov A (2013) Psikhoistoricheskaya voina. Izbor klub: Rus Strateg 1(11):36-71

Higgott R, Stone D (1994) The limits of influence: foreign policy think tanks in Britain and the USA. Rev Int Stud 20(1):15-34

Humphrey C (2002) Does the category 'Postsocialist' still make sense?. In: Hann CM (ed) Postsocialism: ideals, ideologies and practices in Eurasia. Routledge, London, pp. 12-15

INSOR 2010) Rossiya XXI veka: obraz zhelaemogo zavtra.Institut sovremennogo razvitiya, Moscow

Izborskii Club (2012a) Ob Izborskom klube. Available at: http://www.dynacon.ru/ opr/izborsk-c.php (Accessed 18 April 2018)

Izborskii Club (2013) Rozhdenie Izborskogo Kluba. Izbor klub: Rus Strateg 1 (1):2-11

Johnson, B (2018a) Russia's torrent of absurdity is soaked up by an 'infantile' Corbyn. The Sunday Times. 8 April 2018. London

Johnson, B (2018b) Foreign Secretary's Mansion House speech at the Lord Mayor's Easter Banquet 2018. Available at: https:/www.gov.uk/government/speeches/ foreign-secretarys-lord-mayors-easter-banquet-speech-at-mansion-housewednesday-28-march (Accessed 18 April 2018)

Khamraev V et al. (2012) Antivaldai'skaia vozvyshennost'. Kommersant, Moscow

Kopecký P, Mudde C (2003) Uncivil society?: contentious politics in postcommunist Europe. Routledge, London

Laine V (2015) Managed nationalism: Contemporary Russian nationalistic movements and their relationship to the government. FIIA Working Paper. Finnish Institute of International Affairs. Helsinki
Laruelle, M (2009) Inside and around the Kremlin's black box: The new nationalist think tanks in Russia. Stockholm Papers Series. Institute for Security and Development Policy, Stockholm

Laruelle M (2016) The Izborsky Club, or the new conservative Avant-Garde in Russia. Russ Rev 75:626-644

Laruelle M (2017) The Kremlin's ideological ecosystems: Equilibrium and comptetition. PONARS Eurasia Policy Memo No. 493. George Washington University, Washington D.C.

Leshukova PI (2009) Fenomen klubov elit. Sotsiologicheskie Issled 9:33-41

Levada Centre (2018) Obshchestvennoe mnenie 2017-ezhegodnik. Analiticheskii Tsentr Yuriya Levady, Moscow

Linz JJ, Stepan AC (1996) Problems of democratic transition and consolidation: Southern Europe, South America, and post-communist Europe. Johns Hopkins University Press, Baltimore, London

Mankoff J (2011) Russian foreign policy: the return of great power politics. Rowman \& Littlefield Publishers, Lanham, MD

Matthews O (2018) Vladimir Putin's toxic power. The Spectator, London

May T (2017) PM speech to the Lord Mayor's Banquet 2017. Available at https:// www.gov.uk/government/speeches/pm-speech-to-the-lord-mayors-banquet2017 (Accessed 18 April 2018)

Miskimmon A, O’Loughlin B (2017) Russia's narratives of global order: Great power legacies in a polycentric world. Polit Gov 5(3):111-120

Miskimmon A et al. (2013) Strategic narratives: communication power and the new world order. Routledge, New York; London

President of Russia (2018) Interview with Austrian ORF television channel Available at: http://en.kremlin.ru/events/president/news/57675. (Accessed 25 June 2018)

Prier J (2017) Commanding the trend: social media as information warfare. Strateg Stud Q 11(4):50-85

Prozorov S (2008) Russian postcommunism and the end of history. Stud East Eur Thought 60:207-230

Putnam RD et al. (1993) Making democracy work: civic traditions in modern Italy. Princeton University Press, Princeton, N.J.

Rich A (2004) Think tanks, public policy, and the politics of expertise. Cambridge University Press, Cambridge

Russia Today (2014) Justice Ministry drafts motion banning officials' cooperation with 'foreign agent' NGOs. Available at http://rt.com/politics/176044russian-officials-foreigners-ban/ (Accessed 18 April 2018)

Shchipanov M (2008) Klubnaya zhizn' edinorossov. Verchernyaya Moskva, Moscow

Slater W (1998) Imagining Russia: the ideology of Russia's national patriotic opposition, 1985-1995. Department of Slavonic Studies. PhD. University of Cambridge

Stone D (1996) Capturing the political imagination: think tanks and the policy process. Frank Cass, London

The Valdai Discussion Club (2018) Valdai Club Foundation. Available at http:// valdaiclub.com/about/valdai/ (Accessed 18 April 2018)

Tsygankov AP (2014) The strong state in Russia: Development and crisis. Oxford University Press, Oxford

Umland A (2008) Post-Soviet 'Uncivil Society' and the rise of Aleksandr Dugin: A case study of the extraparliamentary radical right in contemporary Russia. $\mathrm{PhD}$. University of Cambridge

Wilson K (2015) Modernization or more of the same in Russia: Was there a "Thaw" under Medvedev? Probl Post-Communism 62(3):145-158

Zhu X (2009) The influence of think tanks in the Chinese policy process: Differen ways and mechanisms. Asian Surv 49(2):333-357

Zygar' M (2016) Vsya kremlevskaya rat': kratkaya istoriya sovremennoi Rossii. Intellektualnaya literatura, Moscow

\section{Data availability}

All data associated with this analysis are available in the paper.

\section{Additional information}

Competing interests: The author declares no competing interests.

Reprints and permission information is available online at http://www.nature.com/ reprints

Publisher's note: Springer Nature remains neutral with regard to jurisdictional claims in published maps and institutional affiliations. 
(c) (i) Open Access This article is licensed under a Creative Commons Attribution 4.0 International License, which permits use, sharing, adaptation, distribution and reproduction in any medium or format, as long as you give appropriate credit to the original author(s) and the source, provide a link to the Creative Commons license, and indicate if changes were made. The images or other third party material in this article are included in the article's Creative Commons license, unless indicated otherwise in a credit line to the material. If material is not included in the article's Creative Commons license and your intended use is not permitted by statutory regulation or exceeds the permitted use, you will need to obtain permission directly from the copyright holder. To view a copy of this license, visit http://creativecommons.org/ licenses/by/4.0/.

(c) The Author(s) 2018 